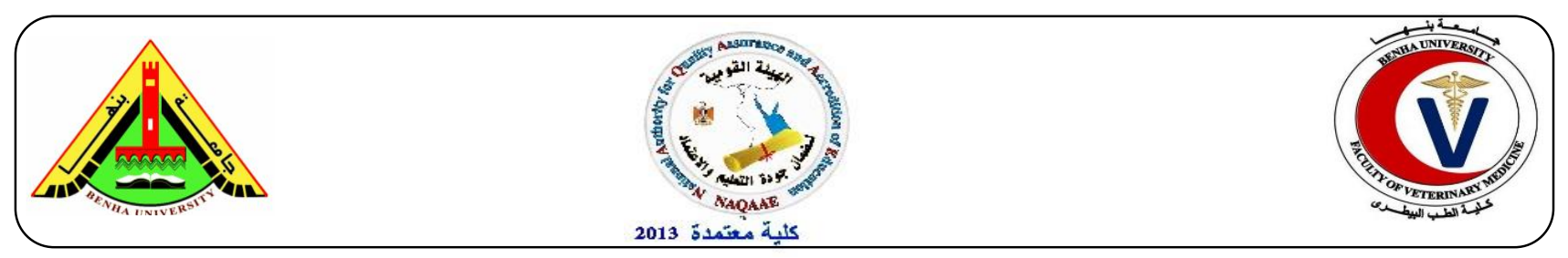

\title{
Evaluation of some quality indices in farmed fish from Kafr Elshiekh governorate
}

\author{
Hassan, M. A ${ }^{1}$, Engy, F.A.M Elbahy ${ }^{2}$, Mai, F. Elsherief ${ }^{2}$ \\ ${ }^{1}$ Department of Food Hygiene and Control, Faculty of Veterinary Medicine, Benha University \\ ${ }^{2}$ Department of Food Hygiene, Animal Health Research Institute, Dokki, Giza.
}

\begin{abstract}
A B S T R A C T
Evaluation of some quality indices was carried out to determine the nutritional value of the most cultured freshwater fishes and to estimate the tolerance of these items to remain in good condition against damage. Quality indices were evaluated in 90 samples from three different fish species (Mugil cephalus, Oreochromis niloticus and Clarias gariepinus) 30 of each were collected at different times from different farms in Kafr Elshiekh Governorate, Egypt. Results of $\mathrm{pH}$, total volatile nitrogen (TVN) "mg N /100g", trimethylamine (TMA)" mg /100g", thiobarbituric acid (TBA)" mg/kg" and peroxide value $(\mathrm{PV}) "$ meqO2/kg" were $6.27 \pm 0.01,6.84 \pm 0.52,2.26 \pm 0.19,1.17 \pm 0.08$ and $2.31 \pm$ 0.27 for Mugil cephalus $6.34 \pm 0.01,8.97 \pm 0.69,3.54 \pm 0.26,1.62 \pm 0.15$ and $3.16 \pm 0.22$ inOreochromis niloticus and $6.46 \pm 0.01,12.31 \pm 1.14,5.70 \pm 0.43,2.89 \pm 0.32$ and $4.74 \pm 0.51$ in Clarias gariepinus, respectively. This study shows superiority of Clarias gariepinus and Mugil cephalus over Oreochromis niloticus in their nutritional value.
\end{abstract}

Keywords: Mugil cephalus, Oreochromis niloticus and Clarias gariepinus, trimethylamine, thiobarbituric acid.

\section{INTRODUCTION}

Fish considered as a desirable and nutritional source of protein and good supply of vitamins and minerals occupying the major part of human diet (Hastein et al., 2006).In addition, fish, regarded as one of the most perishable foods and as a result of wideness of food trade, fish products become more susceptible to rejection due to their poor quality despite the technological developments in fish production (FAO, 2009).

Freshness assurance is one of the most significant goals for the fish industry as freshness is closely related to quality. Determination of post-mortem $\mathrm{pH}$ provides indications of physical properties changes occurring in fish muscle during storage period (Izumi, 2012).

Fish quality involves a wide range of factors; which important for the consumer as nutritional quality, availability and integrity, freshness, eating quality and the obvious physical properties of species, type and size (Abbas et al., 2008).

Volatile amines (TVN, trimethyl-amine) are molecules responsible for fishy odor and flavor in fish which last for several days after catching and they used as measurement for assessing the fish quality (Etienne et al., 2005). 
This study was carried out for evaluation the nutritive value and quality assessment of three fish species (Mugil cephalus, Oreochromis niloticus and Clarias gariepinus) through measurement of general indices $(\mathrm{pH})$, proteolytic indices [total volatile nitrogen (TVN), trimethylamine (TMA)], lipolytic indices(thiobarbituric acid (TBA)) and peroxide value (PV).

\section{Materials and methods}

\subsection{Collection of samples:}

Ninety random samples of farmed fish of Mugil cephalus, Oreochromis niloticus, and Clarias gariepinus (30 of each) were collected from different fish farms located in Kafr Elshiekh Governorate, Egypt. The weight of samples ranged from $200 \mathrm{~g}$ (Mugil cephalus \& Oreochromis niloticus) to $400 \mathrm{~g}$ (Clarias gariepinus). Each sample was kept in a separated plastic bag and preserved in an ice box then transferred to the laboratory (Central laboratory for diagnosis and research of diseases of fish, faculty of veterinary medicine in Kafrelshiekh governorate) and examined chemically as quickly as possible to determine their keeping and safety for human consumption.

\subsection{Quality indices:}

\subsubsection{Determination of $\mathrm{pH}$ :}

$\mathrm{pH}$ of fish samples was determined according to Pearson (2006). Briefly in a blender, approximately $10 \mathrm{~g}$ of the sample were blended in $10 \mathrm{ml}$ of neutralized distilled water. The homogenate was kept at room temperature for 10 minutes with shaking. The $\mathrm{pH}$ value was measured by using an electrical $\mathrm{pH}$ meter (Bye Model 6020, USA). Calibration of $\mathrm{pH}$ meter was done by using two buffer solutions of exactly known $\mathrm{pH}$ (alkaline $\mathrm{pH} 7.01$, acidic $\mathrm{pH}$ 4.01). Therefore, $\mathrm{pH}$ electrode was washed with neutralized water and then introduced into the homogenate.

\subsubsection{Determination of Total Volatile} Nitrogen (TVN):
According to FAO (1980), the technique applied as following:

In a clean dry beaker, $10 \mathrm{~g}$ of the sample were added to $30 \mathrm{ml}$ of distilled water and thoroughly mixed by a blender for 2 minutes. Thus, 2 drops of 0.02 M HCL (Al Biariq Co., $\mathrm{SA})$ were added to bring $\mathrm{pH}$ to 5.2. The homogenate was heated to $70^{\circ} \mathrm{C}$ and cooled to room temperature and filtered. Accurately, the outer ring was filled with $2 \mathrm{ml}$ of the sample extract and $1 \mathrm{ml}$ of saturated potassium carbonate (KCO3) (Shanghai Yixin Chemical Co., Itd, China). The Conway unit was rotated as gently as possible and the dish was covered and incubated at $36^{\circ} \mathrm{C}$ for 2 hours, HCL in inner ring was titrated against $0.01 \mathrm{M} \mathrm{NaOH}$ (Richie products Co., England) by using methyl red indicator (T1 ml) (Sigma-Aldrich, Egypt). Total volatile nitrogen was estimated using the following equation:

$\mathrm{TVN} / 100 \mathrm{~g}=26.88 \times(2-\mathrm{T} 1)$

Where, $\mathrm{T} 1$ was the volume of $\mathrm{NaOH}$ in the titration.

\subsubsection{Determination of Trimethylamine} (TMA):

The method recommened by FAO (1980) was applied using Conway test. Actually, $2 \mathrm{ml}$ of $0.05 \mathrm{M}$ H2SO4 (Shijizhuang Xinlongwei chemical Co., ltd, China) were added into the inner compartment of Conway dish, however, the outer ring of the dish was filled with $2 \mathrm{ml}$ of the sample extract and $1 \mathrm{ml}$ of saturated potassium carbonate (KCO3)( Shanghai Yixin Chemical Co., ltd, China). Furthermore, the dish was covered and incubated at $36^{\circ} \mathrm{C}$ for 2 hours. Thus, $\mathrm{H} 2 \mathrm{SO} 4$ in the inner ring was titrated against $0.01 \mathrm{M} \mathrm{NaOH}$ by using methyl red indicator (T2 $\mathrm{ml})$.

TMA $/ 100 \mathrm{~g}=26.88 \times(2-\mathrm{T} 2)$

Where,

$\mathrm{T} 2=$ volume of $\mathrm{NaOH}$ consumed in the titration.

2.2.4. Determination of Thiobarbituric Acid (TBA): 
The method used for estimation of TBA was applied as mentioned by Pikul et al., (1989). TBA test depends on determination of malonaldehyde (MD) as an end product of lipid peroxidation. Actually, 10 grams of the sample were blended with $50 \mathrm{ml}$ of distilled water in warring blender for 2 minutes. The mixture was transported quantitatively into Kjeldahl flask (C-5420flask pyrex, USA) and washed with an additional $47.5 \mathrm{ml}$ of distilled water. However, $2.5 \mathrm{ml}$ of HCL (Al Biariq Co., SA) were added to $125 \mathrm{ug} / \mathrm{g}$ fat and then a small amount of stones was placed to prevent pumping. The flask was heated at the extreme heat obtainable in the Kjeldahl distillation apparatus (classical macro kjeldahl, Germany). After 10 minutes of boiling, $50 \mathrm{ml}$ of the distillate was collected. Therefore, $5 \mathrm{ml}$ of the distillate were mixed to $5 \mathrm{ml}$ of TBA reagent in $50 \mathrm{ml}$ glass stoppered tube. The contents were mixed and pot in a boiling water bath for 35 minutes. Heating, cooling under tape water for 10 minutes was applied. The optical density of sample for the blank was measured by using Spectrophotometer (UNICAM969AA Spectronic, USA) at a wavelength $538 \mathrm{~nm}$. TBA value $=\mathrm{R} \times 7.8$ (mg malonaldehyde $/ \mathrm{Kg}$ ) Where $=$ Reading of sample against blank

\subsubsection{Determination of Peroxide value:}

Peroxide value was estimated according to the method carried by Asakawa and Matsushita (1978). Briefly, 3g of the sample were mixed with10 $\mathrm{ml}$ chloroform into a $250 \mathrm{ml}$ Erlenmeyer flask. Furthermore, $15 \mathrm{ml}$ acetic acid and $1.0 \mathrm{ml} \mathrm{KI}$ solutions were added and mixed. The mixture was left for 5 minutes in a dark place. Thus, $30 \mathrm{ml}$ distilled water and 1 $\mathrm{ml}$ starch inductor was added. The mixture was titrated with sodium thiosulfate until blue color disappeared. The titration procedure was repeated at least 3 times and the individual results shouldn't vary more than $0.3 \mathrm{ml}$.

\subsection{Statistical analysis.}

The obtained results were statistically evaluated by application of Analysis of
Variance (ANOVA) test according to Feldman et al. (2003).

\section{RESULTS}

$\mathrm{pH}$ values in the examined fish samples were varied from 6.16 to 6.39 with an average of $6.27 \pm 0.01$ in $M$. cephalus. While in $O$. niloticus was ranged from 6.21 to 6.53 with an average of $6.34 \pm 0.01$. In C. gariepinus, it ranged from 6.28 to 6.67 with an average of $6.46 \pm 0.01$ (Table 1). The differences between species were non-significant. $94.44 \%$ of samples were accepted while $5.56 \%$ were not accepted as shown in table (2).

Total Volatile Nitrogen (TVN) values in examined fish samples were varied from 3.78 to $9.41 \mathrm{mg} \mathrm{N} / 100 \mathrm{~g}$ with an average of $6.84 \pm$ $0.52 \mathrm{mg} \mathrm{N} / 100 \mathrm{~g}$ in M. cephalus. In O. niloticus was from 5.17 to $13.09 \mathrm{mg} \mathrm{N} / 100 \mathrm{~g}$ with an average of $8.97 \pm 0.69 \mathrm{mg} \mathrm{N} / 100 \mathrm{~g}$ and from 6.85 to $18.32 \mathrm{mg} \mathrm{N} / 100 \mathrm{~g}$ with an average of $12.31 \pm 1.14 \mathrm{mg} \mathrm{N} / 100 \mathrm{~g}$ in C. gariepinus as in (Table 3).There were high significant differences among examined samples $(\mathrm{P}<0.01)$. All examined samples were accepted as shown in table (4).

Trimethylamine (TMA) values in the examined fish samples showed range from 1.06 to $3.35 \mathrm{mg} / 100 \mathrm{~g}$ with an average of 2.26 $\pm 0.19 \mathrm{mg} / 100 \mathrm{~g}$ in M. cephalus. However, in $O$. niloticus revealed TMA value variedfrom 1.92 to $4.67 \mathrm{mg} / 100 \mathrm{~g}$ with an average of 3.54 $\pm 0.26 \mathrm{mg} / 100 \mathrm{~g}$. C. gariepinus recorded TMA value ranged from 3.18 to $7.41 \mathrm{mg} / 100 \mathrm{~g}$ with an average of $5.70 \pm 0.43 \mathrm{mg} / 100 \mathrm{~g}$ (Table 5).The differeces between samples were significant $(\mathrm{P}<0.05)$. All the examined samples were accepted as shown in table (6). Thiobarbituric acid (TBA) values were varied from 2.09 to $3.65 \mathrm{mg} / \mathrm{kg}$ with an average of $2.89 \pm 0.32$ in Mugil cephalus and from 0.87 to $1.51 \mathrm{mg} / \mathrm{kg}$ with an average of $1.17 \pm 0.08$ $\mathrm{mg} / \mathrm{kg}$ in $O$. niloticus. Meanwhile, $C$. gariepinus recorded TBA value from 1.14 to $1.93 \mathrm{mg} / \mathrm{kg}$ with an average of $1.62 \pm 0.15 \mathrm{mg}$ 
$/ \mathrm{kg}$ (Table 7).The differences among examined fish were highly significant $(\mathrm{P}<0.01)$. All the examined samples were accepted as shown in table (8).

Peroxide value (PV) values in the examined samples were presented in table (9). M.cephalus showed PV value varied from 1.49 to $3.05 \mathrm{meqO} 2 / \mathrm{kg}$ with an average of $2.31 \pm$
$0.27 \mathrm{meqO} 2 / \mathrm{kg}$. While, in Oniloticus was from 2.24 to $3.81 \mathrm{meqO} 2 / \mathrm{kg}$ with an average of $3.16 \pm 0.22 \mathrm{meqO} 2 / \mathrm{kg}$, PV value was from 3.67 to $5.93 \mathrm{meqO} 2 / \mathrm{kg}$ with an average of 4.74 $\pm 0.51 \mathrm{meqO} 2 / \mathrm{kg}$ in C.gariepinus. Differences between fish were high significant $(\mathrm{P}<0.01)$.

Table1: $\mathrm{pH}$ value in the examined fish samples $(\mathrm{n}=30)$

\begin{tabular}{cccc} 
Fish species & Min & Max & Mean \pm S.E \\
\hline $\begin{array}{c}\text { Mugil cephalus } \\
\text { Oreochromis niloticus }\end{array}$ & 6.16 & 6.39 & $6.27 \pm 0.01$ \\
Clarias gariepinus & 6.21 & 6.53 & $6.34 \pm 0.01$ \\
& 6.28 & 6.67 & $6.46 \pm 0.01$
\end{tabular}

NS $=$ Non-significant differences

Table 2: Acceptability of the examined farmed fishes according to their $\mathrm{pH}$ values $(\mathrm{n}=30)$

\begin{tabular}{cccccc}
\hline & Maximum & \multicolumn{2}{c}{ Accepted samples } & \multicolumn{2}{c}{ Unaccepted samples } \\
\cline { 3 - 6 } Fish species & $\begin{array}{c}\text { Permissible } \\
\text { Limit } *\end{array}$ & No. & $\%$ & No. & $\%$ \\
\cline { 3 - 6 } Mugil cephalus & 6.5 & 30 & 100 & 0 & 0 \\
Oreochromis niloticus & 6.5 & 29 & 96.7 & 1 & 3.3 \\
Clarias gariepinus & 6.5 & 26 & 86.7 & 4 & 13.3 \\
Total (90) & & 85 & 94.44 & 5 & 5.56 \\
\hline
\end{tabular}

* Egyptian Organization for Standardization "EOS" (2005).

Table 3: Total Volatile Nitrogen (TVN) “mg N/100g” in the examined fish samples (n=30)

\begin{tabular}{cccc} 
Fish species & Min & Max & Mean \pm S.E \\
\cline { 2 - 4 } Mugil cephalus & 3.78 & 9.41 & $6.84 \pm 0.52$ \\
Oreochromis niloticus & 5.17 & 13.09 & $8.97 \pm 0.69$ \\
Clarias gariepinus & 6.85 & 18.32 & $12.31 \pm 1.14$
\end{tabular}

$++=$ High significant differences $(\mathrm{P}<0.01)$ 
Hassan et al. (2019). BVMJ-36(2): 210-218

Table 4: Acceptability of the examined farm fishes according to their TVN values $(n=30)$

\begin{tabular}{llllll}
\hline \multirow{2}{*}{ Fish species } & $\begin{array}{l}\text { Maximum } \\
\text { Permissible } \\
\text { Limit (mg\%)* }\end{array}$ & \multicolumn{2}{c}{ Accepted samples } & \multicolumn{2}{c}{ Unaccepted samples } \\
\cline { 3 - 6 } Mugil cephalus & 30 & 30 & 100 & 0 & No. \\
\cline { 3 - 6 } Oreochromis niloticus & 30 & 30 & 100 & 0 & 0 \\
Clarias gariepinus & 30 & 30 & 100 & 0 & 0 \\
Total (90) & & 90 & 100 & 0 & 0 \\
\hline
\end{tabular}

* Egyptian Organization for Standardization "EOS" (2005).

Table 5: Statistical analytical results of Trimethylamine (TMA) "mg/100g" in the examined samples of farm fishes $(n=30)$

Fish species

Mugil cephalus

Oreochromis niloticus

Clarias gariepinus

\begin{tabular}{lll} 
Min & Max & Mean \pm S.E \\
\hline 1.06 & 3.35 & $2.26 \pm 0.19$
\end{tabular}

1.92

4.67

$3.54 \pm 0.26$

3.18

7.41

$5.70 \pm 0.43$

$+=$ Significant differences $(\mathrm{P}<0.05)$

Table 6: Acceptability of the examined farmed fishes according to their TMA values $(n=30)$

\begin{tabular}{llllll}
\hline \multirow{2}{*}{ Fish species } & Maximum & \multicolumn{2}{c}{ Accepted samples } & \multicolumn{2}{c}{ Unaccepted samples } \\
\cline { 3 - 6 } Permissible & Limit $(\mathrm{mg} \%)^{*}$ & No. & $\%$ & No. & $\%$ \\
\cline { 3 - 6 } Mugil cephalus & 10 & 30 & 100 & 0 & 0 \\
Oreochromisniloticus & 10 & 30 & 100 & 0 & 0 \\
Clariasgariepinus & 10 & 30 & 100 & 0 & 0 \\
Total (90) & & 90 & 100 & 0 & 0 \\
\hline
\end{tabular}

* Egyptian Organization for Standardization "EOS" (2005)

Table 7: Thiobarbituric acid (TBA) "mg/Kg" in the examined fish samples ( $\mathrm{n}=30$ )

Fish species

Mugil cephalus

Oreochromis niloticus

Clarias gariepinus

\begin{tabular}{lll} 
Min & Max & Mean \pm S.E \\
\hline 2.09 & 3.65 & $2.89 \pm 0.32$ \\
0.87 & 1.51 & $1.17 \pm 0.08$ \\
1.14 & 1.93 & $1.62 \pm 0.15$
\end{tabular}

$++=$ High significant differences $(\mathrm{P}<0.01)$ 
Table 8: Acceptability of the examined farmed fish according to their TBA values

\begin{tabular}{|c|c|c|c|c|c|}
\hline \multirow{2}{*}{ Fish species } & \multirow{2}{*}{$\begin{array}{l}\text { Maximum } \\
\text { Permissible Limit } \\
(\mathrm{mg} / \mathrm{Kg})^{*}\end{array}$} & \multicolumn{2}{|c|}{ Accepted samples } & \multicolumn{2}{|c|}{ Unaccepted samples } \\
\hline & & No. & $\%$ & No. & $\%$ \\
\hline Mugil cephalus & 10 & 30 & 100 & 0 & 0 \\
\hline Oreochromis niloticus & 10 & 30 & 100 & 0 & 0 \\
\hline Clarias gariepinus & 10 & 30 & 100 & 0 & 0 \\
\hline Total (90) & & 90 & 100 & 0 & 0 \\
\hline
\end{tabular}

* Egyptian Organization for Standardization "EOS" (2005)

Table 9: Peroxide value (PV) "meqO2/kg" in the examined fish samples $(\mathrm{n}=30)$

\begin{tabular}{llll} 
Fish species & Min & Max & Mean \pm S.E \\
\hline Mugil cephalus & 1.49 & 3.05 & $2.31 \pm 0.27$ \\
Oreochromis niloticus & 2.24 & 3.81 & $3.16 \pm 0.22$ \\
Clarias gariepinus & 3.67 & 5.93 & $4.74 \pm 0.51$ \\
\hline
\end{tabular}

$++=$ High significant differences $(\mathrm{P}<0.01)$

\section{DISCUSSION}

Chemical indices such as (pH, TVN, TMA, TBA and PV) are the most widely used parameters to evaluate fish quality (ElMarrakchi et al., 1990). In this study, three type of farmed fish (M. cephalus, O. niloticus and C. gariepinus) were examined chemically to determine their keeping and safety for human consumption.

Concerning $\mathrm{pH}$, the obtained results were nearly closed to those of Ibrahim (2017) who examined $M$. cephalus and $O$. niloticus and lower than those obtained by Sathivel (2005). $\mathrm{pH}$ values was a suitable index for freshness assessment and it can be useful as a guideline for quality of fish (Ruiz Capillas and Moral, 2001). The differences between species were non-significant. Egyptian Organization for Standardization (EOS, 2005) had reported the critical limits of $\mathrm{pH}$ for chilled fish portion which should not be more than 6.5. Therefore, $94.44 \%$ of samples were accepted while $5.56 \%$ were not accepted with $100 \%$ accepted $C$. gariepinus.
Regarding to TVN, the obtained results were higher than those of Ibrahim (2017) who recorded TVN in $M$. cephalus with an average on f $5.65 \pm 0.39$ and $7.09 \pm 0.54$ in $O$. niloticus and nearly balanced with those of Mahmoud (1990). Generally, TVN is synthesized by reaction from protein mainly as a result of microbial activity (Gamal et al., 2011). Thus, TVN levels are affected by the method of catch, post mortem treatment and storage temperature as well as it differ according to fish species (Nazemroaya et al., 2011). There were high significant differences among examined samples $(\mathrm{P}<0.01)$. According to EOS (2005) $100 \%$ of the examined fish samples were accepted as their values are lower than the maximum permissible limits.

TMA regarded as a good index of quality for many fish species by Baixas-Nogueras et al. (2002). These results were nearly similar to those of Mahmoud (1990) and Ibrahim (2017). Huss, (1995)reported that TMA differs according to species and also it is affected by storage time and catching season. The 
differences between samples were significant $(\mathrm{P}<0.05)$. According to EOS (2005), the permissible limit of TMA was 10 . Hence, all the examined samples were accepted.

These results were nearly similar to those of Ibrahim (2017), higher than those obtained by Gulsun et al. (2009) and Nazemroaya et al. (2011) and lower than that obtained by Vafakhah et al. (2014).

TBA is a significant quality index for fatty fish (Lynch and Frci, 1993). The higher lipids content of fish the higher TBA value in fish (Caponia et al., 2004). The TBA factor is responsible for a rancid flavor, off odor, color as well as texture deterioration (Olafsdottir et al., 1997). The differences among examined fish were highly significant $(\mathrm{P}<0.01)$. According to Egyptian Organization for Standardization EOS (2005), the permissible limit of TBA was 10. Subsequently, all the examined samples were accepted

Peroxide value is a good indicator of fat oxidation (rancidity) (Adeyemi et al., 2013). The results of peroxide value (PV) were lower than those obtained by Famurewa et al. (2017) who recorded Peroxide value in $C$. gariepinus ranged from 4.60 to $7.37 \mathrm{meq} \mathrm{O} / \mathrm{kg}$. Peroxide value is a primary indicator of fat oxidation (rancidity) (Adeyemi et al., 2013). When peroxide value exceeds $10-20 \mathrm{meq} \mathrm{O} 2 / \mathrm{Kg}$, rancid taste and smell occur (Connell, 1995). Therefore, it can be concluded that the values from this study are within the acceptable limits of spoilage. Differences between fish were high significant $(\mathrm{P}<0.01)$.

In conclusion, the present study indicated that chemical indices as ( $\mathrm{pH}, \mathrm{TVN}, \mathrm{TMA}, \mathrm{TBA}$ and PV) are the most effective indicators for quality, freshness as well as nutritive value of fish. TVN and TMA appear as reliable indicators for determination of proteolytic activity, however, TBA is a good index for demonstration of fat rancidity. In contrast, $\mathrm{pH}$ is a poor indicator of fish quality as it is widely range of variation among fish species. This study shows superiority of $C$. gariepinus over M.cephalus and $O$. niloticus except in TBA which was higher in $M$. cephalus due to its high lipid value than other two species. $C$. Gariepinus and $M$. cephalus considered more valuable than $O$. niloticus. Therefore, it was recommend that chemical assessment of fish samples as a rapid, accurate method and gives good indication of fish quality should be done.

\section{CONCLUSION}

Meat selected samples are considered a good medium for the growth of salmonella and the production of toxins. The lowest contamination was in M.cephalus flesh meat but the highest contamination was in minced beef the presence of this bacterial species in such samples is a result of contamination along production lines include slaughtering, preparation, distribution, storage, packaging, and sale of the products. This subsequently contributes to health risks to the consumer. So, these samples need carefully control to protect consumers against food poisoning.

\section{REFERENCES}

Abbas, K. A., Mohamed, M., Jamilah, B. and Ebrahimian, M. 2008. A review on correlations between fish freshness and $\mathrm{pH}$ during cold storage.American Journal of Biochemistry and Biotechnology 4, 416-421.

Asakawa, S. and Matsushita, T. 1978. Colorimetric determination of peroxide value with potassium iodide-silica gel reagent. Journal of American Oil Chemists Society 55,619-620.

Baixas-Nogueras S., Bover-Cid, S., Veciana Nogue, T. and Vidal-Carou, M.C. 2002. Chemical and sensory changes in Mediterranean hake (Merlucciusmerluccius) under refrigeration $\left(6-8^{\circ} \mathrm{C}\right)$ and stored in ice. 
Journal of Agriculture and Food Chemistry 50, 6504-6510.

Caponio, F., A. Lestingi, C. Summo, M. T. Bilancia, and V. Laudadio 2004. Chemical characteristics and lipid fraction quality of sardines (Sardinapilchardus W.) influence of sex and length. Journal of Applied Ichthyology 20, 630-535.

Christine, L., D., Cheret, R., Tylor, R. and VerrozBagins, V. 2006.Trends in postmortem aging in fish-understanding of proteolysis and disorganization of the myofibrillar structure. Food Science and Nutrition 46, 409-421.

Connell, J. J. 1995. Control of fish quality. 4th Edition. Fishing News Books, Farnham. England.

Egyptian Organization for Standardization and Quality Control 2005. Reports related to No. 3439, 2005 for chilled fish. Egyptian Standards, Ministry of Industry, Egypt.

El-Marrakchi, A., Bennour, M., Bouchriti, N., Hamama, A. and Tagafait, H. 1990. Sensory, chemical, and microbiological assessment of Moroccan sardines (Sardinapilchardus) stored in ice. Journal of Food Protection 53, 600-605.

Etienne, M., Ifremer and Nantes 2005. Methods for chemical quality assessment volatile amines as criteria for chemical quality assessment sea food Plus Traceability Valid 16-22.

Famurewa, J. A. V., Akise, O. G. and Ogunbodede, T. 2017. Effect of storage methods on the nutritional qualities of African Cat fish (Clariasgariepinus). Academic Journal11, 223-233.

FAO, 1980. Food and Agriculture Organization Manual of Food Quality Control, United Nation, Rome, Italy. Seafood, Washington DC.

FAO, 2009. Food and Agriculture Organization Fisheries and Aquaculture
Department of the United Nations, Rome.

Feldman, D., Ganon, J., Haffman, R. and Simpson, J. 2003. The solution for data analysis and presentation graphics. Second Edn., Abacus Lancripts, Inc., Berkeley, USA.

Gamal, F. M., Eman, M. Hegazy and Abdelatef, M. 2011. Physiochemical properties and mycotoxins contents of Tilapia fish fillet after solar drying and storage. Global Veterinaria 7,138-148.

Gulsun, O., Esmeray, K., Serhat, O. and Faith O. 2009. Sensory, Microbiological and chemical assessment of the freshness of red mullet (Mullus barbatus) and goldband goatfish (Upeneusmoluccensis) during storage in ice. Food Chemistry 114, 505-510.

Hastein, T., Hjeltnes, B., Lillehaug, A., UtneSkare, J., Berntssen, M., Lundebye, A. K. 2006. Food safety hazards that occur during the production stage, challenges for fish farming and the fishing industry. Revue scientifique et technique 25, 607-625.

Huss, H. H. 1995. Quality and quality changes in fresh fish. Rome, FAO Fisheries Technical paper 348 .

Ibrahim, M. S. A. 2017. Chemical indices for different types of fish and shell fish spoilage. Thesis, Master of Veterinary Medicine, University of Benha, Egypt.

Izumi S. 2012.spectral changes in fillet of Atlantic salmon as affect by freshness loss and spoilage during cold storage. A dissertation for degree of philosophiae doctor, Faculty of Bioscience, Fisheries and economics, Department of Norwegian College of fishery science.

Lynch, S. M. and Frci, B. 1993. Mechanism of copper- and iron- dependent oxidative modification of human low density lipoprotein. Journal of Lipid Research $34,1745-1753$. 
Mahmoud, Y. E. 1990. Studies on the sanitary condition of some Nile fish marketed in Kalyobia governorate. Thesis, Master. of Veterinary Medicine. University of Benha, Egypt.

Nazemroaya, S.,Sahari, M. A. and Rezaei, M. 2011.Identification of fatty acid in Mackerel and shark fillets and their change during six months of frozen storage. Agriculture Science Technology Journal 13, 553-566.

Olafsdottir, $\quad$ G., $\quad$ Martinsdottir, E.,Ochlenschlager, J.,Dalgaard, P., Jensen, B.,Undeland, I., Mack, I. M.,Henehan, G., Nielsen, J. and Nielsen, H. 1997. Methods to evaluate fish freshness in rear and industry. Trends in Food Science and Technology $8,258-265$.

Pearson, D. 2006. Chemical Analysis of Food. eight $^{\text {th }}$ edn., Churchill Living stone, Edinburg, London.

Pikul, J., Leszezynski, D. E. and Kummerow, F. 1989. Evaluation of three modified TBA methods for measuring lipid oxidation in chicken meat. Agriculture journal. Food Chemistry 37, 1309.

Ruiz-Capillas, C. and Moral, A. 2001. Correlation between biochemical and sensory quality indices in hake stored in ice. Food research international 34, 441447.

Sathivel, S. 2005. Chitosan and protein coating affect yield, moisture loss, and lipid oxidation of apple pink salmon fillets during frozen storage. Journal of Food Science 70, 445-459.

Vafakhah, F. O. H. and Javaheri, B. M. 2014. Lipid quality in benni (Barbus sharpeyi) fillets during ice storage. Internationnal Journal of Biosciences 4,109-116. 